\title{
"A Community College with Ivory Tower Pretensions": Perceptions of a New University
}

Sierra McKenzie and Alyson E. King

University of Ontario Institute of Technology

\begin{abstract}
The ways in which a new university, the University of Ontario Institute of Technology (UOIT), was represented in local, regional, and national newspapers highlight the difficulties of identity creation for organizations. Drawing on theories of organizational identity and supplemented by interviews with UOIT's founding members, a qualitative analysis of newspaper articles about UOIT published between 2001 and 2004 demonstrates that the words and phrases used in these articles played an important role in establishing an image of UOIT that continues to impact its identity. These news reports also illustrate the complex relationships that existed between UOIT and its geographical, educational, and political contexts. Although UOIT was founded as a four-year baccalaureate degree-granting university, it was linked with its well-established neighbour, Durham College, with which it shared land and services. As a result, UOIT was viewed by some as no more than a "community college with ivory tower pretensions."
\end{abstract}

\section{Résumé}

La représentation de l'Institut universitaire de technologie de l'Ontario (IUTO) dans la presse locale, régionale et nationale met en évidence les difficultés de création d'une identité corporative. Une analyse qualitative des articles sur l'IUTO, publiés entre 2001 et 2004, étoffés par des entretiens avec les membres fondateurs de l'IUTO, démontre, en s'appuyant sur les théories de l'identité organisationnelle, que leur contenu a joué un rôle important dans la définition de l'image de l'IUTO qui affecte encore son identité. Ces reportages illustrent aussi les relations complexes entre l'UOIT et son cadre géographique, éducatif et politique. Bien que l'IUTO soit une université décernant des baccalauréats de quatre ans, il est lié à son voisin bien établi, 
le Collège communautaire Durham, car il partage avec lui les terres et les services. En conséquence, on considère parfois l'IUTO comme rien de plus qu'un « collège communautaire enfermé dans une tour d'ivoire ».

When the University of Ontario Institute of Technology (UOIT) emerged in 2003 as Ontario's first new university in 40 years, it faced the challenge of creating an organizational identity that would enable its future success, help the university integrate into the local community, and attract students, professors, and partnerships. Furthermore, this identity would define where the new institution would be placed in the educational landscape in relation to other post-secondary institutions and its political affiliations, which would impact funding and support. While the creation of UOIT's identity can be observed from an insider's viewpoint through interviews with founding students, staff, and faculty, as well as through an outsider's viewpoint accessed through the press coverage, we argue that this identity-creation process was significantly mediated by the debates about and the framing of the university as these were reported in local and national newspapers. This paper seeks to understand the ways in which the press framed the identity of UOIT at its founding, to afford an understanding of the university as it developed a relationship with the local community, established its place within Ontario's and Canada's educational landscapes, and negotiated Ontario's political minefield.

\section{Context: The First New University in Ontario in 40 Years}

On May 9, 2001, the Ontario government announced that $\$ 60$ million had been dedicated to the creation of a new university in Oshawa, Ontario, located 45 minutes' drive east of Toronto. A year later, the provincial government passed Bill 109, Schedule O, the University of Ontario Institute of Technology Act, 2002. UOIT's doors opened to 947 students in September 2003. The period between the first announcement in 2001 and the end of its first year as a university was one during which the university's role and identity in Ontario's post-secondary education landscape was debated, discussed, critiqued, and decried. UOIT's founding president, Gary Polonsky, was also the president of the wellestablished Durham College, ${ }^{1}$ which had been located in the north end of Oshawa since its founding in 1967. In addition, the university and college shared land and many services (e.g., computer and IT services, the student athletic centre, the library). While the university is a full-fledged, four-year, degree-granting university, many people initially saw its proximity to and ties with the college as a sign that it was an extension of the college or that the college was being given degree-granting status. That these perceptions were reiterated regularly in the local and national newspapers created a perception that UOIT was little more than a "trumped-up college," in spite of its legal status as a university. As UOIT approached its $10^{\text {th }}$ anniversary in 2014, an oral history project of the founding years of the university collected 97 interviews with students, founding deans and faculty members, administrative staff, and others involved in the planning and implementation of the new university. In addition, newspaper reports about the university between 2001 and 2004 were examined. While analysis of the data from the interviews is ongoing, preliminary findings indicate that many students, faculty members, and staff came to UOIT to be part of what they saw as an exciting opportunity to build a new university. 


\section{Literature Review: Organizational Identity, Reputation, and Legitimacy}

The concepts of identity in general, and organizational identity in particular, have been debated, defined, and redefined over many years (see, for example, Alessandri, Yang, \& Kinsey, 2006; Baron, 2004; Brown, Dacin, Pratt, \& Whetten, 2006; Dutton \& Dukerich, 1991; Glynn \& Abzug, 2002; Glynn \& Navis, 2013; Hsu \& Hannan, 2005; Whetten, 2006). Albert and Whetten (1985) defined organizational identity as "that which is most central, enduring, and distinctive about an organization" (cited in Whetten \& Mackey, 2002, p. 394); in other words, an organization must have (1) a "claimed central character" based on a key aspect of the organization; (2) "temporal continuity" or stability and "sameness over time"; and (3) "distinctiveness" in comparison with its competitors and similar organizations (Albert \& Whetten, 1985, cited in He \& Baruch, 2009, pp. 576-577). Debates over the specific interpretation of their definition align around two distinctions: "identity-as-shared perceptions among members versus identity-as-institutionalized claims" (Whetten \& Mackey, 2002, p. 395).

Brown and colleagues (2006) identified four viewpoints from which to analyse an organization's identity: (1) how organizational insiders or members perceive the organization; (2) whether key stakeholder groups perceive the organization in the ways the organization intends ("intended associations" and "intended image"); (3) how members of the organization believe outsiders perceive the organization ("construed associations" and "construed image"); and (4) the reputation of the organization (pp. 102-104). King and Whetten (2008) saw a link between legitimacy and reputation. For a university, legitimacy is tied to meeting the accreditation requirements set for all universities, the university's reputation, and its identity. For a new university, even once accreditation requirements are met, reputation is still being built and initial organizational identity is being created around the ideas, interests, and goals of the founding members. A strong, clear, and distinct identity is necessary because it affords legitimacy for the future of the institution and facilitates the organization's ability to operate effectively in its social environment (Oelsner, 2013). An identity based on the foundational choices, however, is not absolute; there is room for change as circumstances evolve and shift. Nonetheless, once such foundational choices are made, they tend to form the functional equivalent to individuals' inherent characteristics in identity formation. In other words, where an individual's identity is shaped in part by physical characteristics (Stets \& Burke, 2000), an organization's inherent characteristics lie in the formative decisions made at the founding of the organization.

Ressler and Abratt (2009) explored how different groups perceive university reputation. They noted that a university's reputation will be impacted by "the collective experiences of each stakeholder group and how the school is perceived to treat its various stakeholders" (p. 39). For a new university, the key stakeholders-students, faculty, alumni, employers, and so on-will not be clearly established until after the university has been operating for some amount of time. Alumni, for example, will not begin to exist until after the first cohort of students graduates. In addition, students are not simply passive consumers in a university; they are active collaborators and "designer[s] of the education product and in essence becomes a product of the university on graduation" (Ressler \& Abratt, 2009, p. 39). Reputation is important for a university to track and manage; how- 
ever, in the early years of the university, we argue that reputation was virtually nonexistent and was in fact being created alongside the university's identity. Reputation is built on the shared stakeholders' perceptions of the organization over time (Alessandri et al., 2006) and is tied to the organization's identity. Interactions with that identity produce an organizational image; reputation is created over time through impressions of that image (Alessandri et al., 2006). Our focus here is on the very early stages of the creation of a university identity-an identity that will eventually lead to a reputation.

Organizational ecology has been defined by Hsu and Hannan (2005) as macro-research aimed at finding explanations for "change in the world of organizations" (p. 474) and is relevant to our project because it places importance on "the perceptions, beliefs, and actions of contemporaneous audiences" in interpreting and understanding the codes or rules that make up an organization's identity (p. 475-476). Drawing on Baron's (2004) exploration of organizational ecology, the dimensions of sharpness/resonance and focus are tied to how a university fits into the group of organizations recognized as universities. A new university must negotiate a balance between being like other universities in its region (e.g., in Ontario or in Canada) while also having a degree of uniqueness to differentiate it from those other universities. Sharpness in an organization makes it recognizable to its constituents (such as parents, potential students, teachers, and guidance counsellors), while resonance refers to the uniqueness of the organization-those components that differentiate it along social, political, cultural, economic, ethnic, and/or religious lines (p. 11). UOIT differentiated itself from other Ontario universities with its emphasis on technology and on professional, career-oriented programs (e.g., criminology, engineering, business, information technology, health science, nuclear science). UOIT's “focus," a concept Baron (2004) argued is a claim about identity, is related to its legislated mandate as a university offering professionally oriented programs. Similarly, the third dimension of identity, what Baron (2004) called authenticity, was being created in the early years of UOIT's existence. An authentic identity is one that is credible and has a "non-economic logic for action" (Baron, 2004, p. 14). In order for universities to be seen as authentic (or "real") universities, for example, they can only consider hiring those with appropriate credentials (highly focused work force) and must treat their constituents, both faculty members and students, in a principled manner. In a similar way, Hsu and Hannan (2005) argued that if audiences perceive an organization as not authentic or principled, it is not abiding by the social codes that determine legitimacy. In this sense, outsiders are important to the creation of organizational identity, and identity is more than the observable properties of the organization. In other words, organizational identity is not defined solely by the members of an organization, the insiders.

News reports are key in revealing whether and how organizations abide by social codes and in revealing legitimacy. Kim, Carvalho, and Cooksey (2007) demonstrated that greater exposure to negative press coverage is associated with unfavourable perceptions and decreased public support, and they suggested that building a positive relationship with the community through open communication is the best way to gain public support. Newspapers play a crucial role in mediating public relations between universities and their communities. According to Leeper and Leeper (2006), when the University of Missouri-Kansas City (UMKC) encountered a public relations crisis after it announced the demolition of 100 neighbouring houses to make space for sporting fields, the cover- 
age in the local paper highlighted the failure to involve the affected publics in the creation of the university's master plan. The case of UMKC highlights the need for two-way communication between a university and the surrounding community and demonstrates the power of newspapers to frame issues involving a university's relationship with the local public. Moving beyond a public relations perspective, our focus on media reports fits with organizational reputation research "because the media reflect and influence the opinions of their audiences" (Carter \& Deephouse, 1999, p. 311). Stories in the media can have a significant influence on how an organization's potential audience, such as prospective students (and their parents), views it.

\section{Conceptual Framework}

He and Baruch (2009) note that the study of an organization's identity can be based on one or more theoretical approaches: the organization as social actor, as socially constructed, and as narrative. Our larger study utilizes all three of these approaches in that UOIT plays an active role in its surrounding local and broader geographical, educational, and political communities. Its identity is socially constructed by its representations in the local media and in the founding members' vision. Finally, the narrative history of UOIT has been collected in an oral history project through interviews with the founding members of the administration, the faculty, and the students.

While we draw on preliminary analyses of selected interviews to help place the news reports into a broader context, this article specifically examines newspaper articles about the founding and early years of the university and draws on research about organizational identity, ecology, and reputation to make sense of the impact of the media in the creation of one university's identity. For the purposes of this paper, we draw on a general understanding that organizational identity is something that evolves over time and grows out of (1) purposeful and intentional administrative (insider) efforts to create an identity or image and (2) interactions with stakeholders and audiences (outsiders). Insider perspectives are gleaned from selected interviews, primarily with faculty and staff, while the outsider viewpoints are drawn from the newspaper articles. These articles provide the voices of politicians, representatives from other universities and affiliated organizations (e.g., the Ontario University Student Association), and the general public. Although these perspectives are, of course, filtered by the reporters writing the stories and the newspapers that publish them, they nonetheless act to present the university's identity to the public in a widely disseminated format.

\section{Methodology}

Using the university names to generate keywords in a search of Lexis Nexis Canada and the Metroland database (DurhamRegion.com), 375 articles were found that mentioned the University of Ontario Institute of Technology or the Ontario Institute of Technology. Of these, 152 only mentioned the university in passing or were not about the university. The remaining 198 articles were closely read to determine key themes or frames, which form our thematic word pools (see Table 1). These news stories framed and positioned UOIT in three ways: geographic labels that described the institution's physical location and alluded to the university's associations, catchment area, influence, and prestige; the 
educational landscape that placed UOIT in the broader context of the system of higher education in Ontario and Canada; and the provincial political situation, which demonstrated both the government's perception of the role of universities and how UOIT was perceived as a political manoeuver. These three themes were also apparent in several of the 97 interviews conducted in the Voices of UOIT project. For this article on UOIT's organizational identity, transcripts of the interviews were searched for references to geographic location, the naming of the university, and the political roots of the university. A close reading of relevant transcripts was undertaken to determine whether what interviewees remembered about the founding years coincided with the findings from the analysis of the news reports. Although the student interviews generally did not indicate any awareness of or confusion about the nature of UOIT, the interviews with faculty and staff revealed purposeful efforts to counterbalance misperceptions about the university that were reported in the newspapers.

Table 1.

Thematic Word Pools

\begin{tabular}{lll}
\hline Geography-related words & Politically-related words & Education-related words \\
\hline - Windfields Farms & - Conservative or Tory & - Technical/technology university \\
- Oshawa & - Liberal & - College \\
- Durham Region (or "The & - Politicians' names (i.e., & - University-college \\
Region") & Jim Flaherty, Janet Ecker) & - University \\
- Northumberland County & - City Councillors of Osha- & - Degree-granting \\
- East of Toronto & wa (i.e., Nancy Diamond) & - Diploma \\
- GTA (Greater Toronto & - Premier Dalton McGuinty & - Certificate \\
Area) & - Premier Mike Harris & - Job-related, job training \\
- Ontario (or "the prov- & - Private sector & - Professional education \\
ince") & - Ontario government (or & - Institution \\
- Canada & Queen's Park) & - Institute of Technology \\
& & - Durham College \\
\hline
\end{tabular}

Most articles came from three newspapers, the Toronto Star, The Globe and Mail, and the local newspaper published by Metroland. We limited our search to articles published between 2001 and 2004 because they reflected the initial reactions to the university's formation through their descriptions of and commentary on the university as a new entity. Articles were read critically, and phrases or passages that worked to create organizational identity were highlighted according to the thematic word pools. For instance, phrases relating to geographic context were divided based on whether they referred to the city, region, province, or country. Phrases related to the educational and political contexts proved more challenging to divide into themes because of the more abstract nature of these descriptions.

The articles were then critically examined to identify emerging trends and what we term critical diction moments. Trends were identified by the frequency of similar word clusters, while critical diction moments were the points at which reporters used particular 
words, phrases, or sentences that revealed underlying values and biases. In other words, we looked at the context in which the words were used and what that usage implied. By drawing attention to critical diction moments, rather than tallying the occurrences of certain words and phrases, we retain the emphasis on a qualitative assessment of those words and phrases in the context of a new university establishing its identity, reputation, and legitimacy. In this case, counting the number of instances will not reveal important details because the inferred or implied meaning of the words and phrases in the particular context matter more than frequency. For instance, UOIT is referred to as a university in the majority of the stories; however, the times when it is referred to as a "technical university" are critical diction moments because the qualifying word "technical" reveals underlying assumptions and judgements that served to undermine the image of a "real" university. When paired with interview excerpts from the Voices of UOIT oral history project, the trends in the press help to show how the university's identity was being created and how it was perceived, while revealing assumptions and biases.

\section{Analysis and Discussion: Fitting In and Standing Out}

The case of UOIT makes an interesting study because its mandate as a professional, market-oriented university and its original association with Durham College were unique and controversial and continue to drive some aspects of its identity and public image. As Oelsner (2013) suggested, a weak or erroneous public identity is a "fatal flaw for organizations" (p. 117). However, the strong leadership of Gary Polonsky, founding president of UOIT and former president of Durham College, was key in the creation of a public identity for the university. As Oelsner (2013) also pointed out, "inspired leadership" is influential in "identity articulation" (p. 118). Similarly, the social environment in which an organization operates shapes its organizational identity (Oelsner, 2013). For UOIT, its social environment is made up of the local, regional, provincial, and national contexts. As a new university, following Albert and Whetten (Whetton 2006), UOIT's claimed character and uniqueness were reiterated by Polonsky and other founding members in references to its professional programs and structure as a laptop university, while continuity could only be highlighted as a goal for the future.

\section{Geographic Context}

The geographic context of UOIT plays a significant role in the creation of its organizational identity. The concentric circles in Figure 1 represent the layers of geographic context and illustrate the overlapping catchment areas and the regions to which the university needed to appeal to both establish its identity and attract the necessary number of students. In this sense, the circles are like ripples in a pond-the university was created on Windfields Farms land in Oshawa, Ontario, but its reach extended to Canadian students outside Ontario and to international students. Figure 1 also provides a representation of the identity referents of the composite identity (King \& Whetten, 2008) pursued by the university. Rather than a hierarchical list, the concentric circles represent identities that overlap and widen as one moves further from the actual geographic location of the university. The immediate area of Windfields Farms-Oshawa and the Durham Regionprovides ties to a local community that supported the creation of a new university and 
provided a population from which to draw the original cohort of students. Yet, in order for the university to grow in size and status, it was important for its founders to move the university towards the wider rings of provincial, national, and international identities.

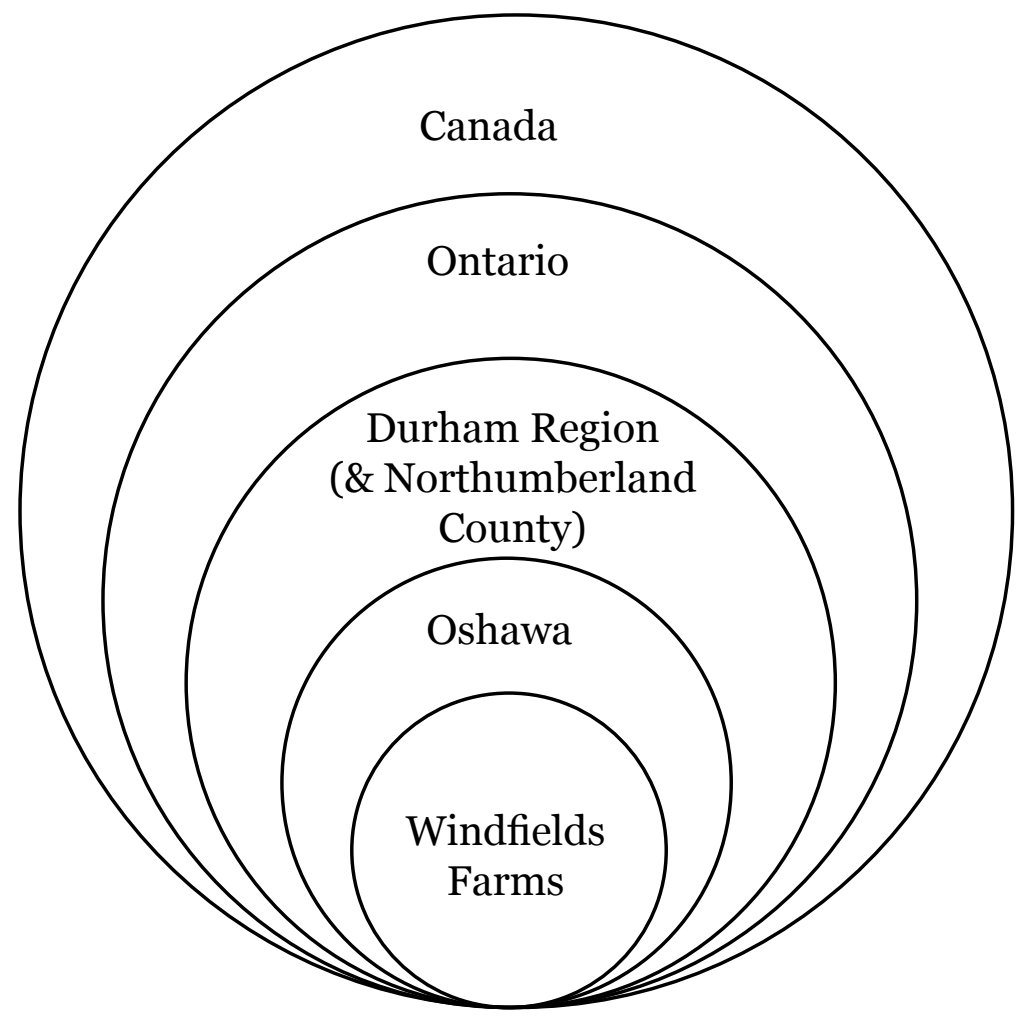

Figure 1. Layers of geographic context reflecting identity referents

At first glance, the geographic descriptors journalists used to identify the location of UOIT may not seem overly impactful; however, research suggests that associations with locations such as cities or countries affect brand perceptions. For instance, Li and Wyer (1994) argued that country of origin can act as an important quality signal when little other information is present. Extending this finding, we argue that such geographic associations also include regions and cities. Geographic labels, therefore, may be extremely important during the initial branding of the university, as the locations associated with the university may affect perceptions of it when little else is known about it. Chapleo (2010) made a similar argument, finding that the branding of higher education institutions in the United Kingdom could be influenced positively by location, that local residents believe that universities have the power to "transform" (p. 177) the city or town in which they are located, and that synergy can exist between the university's brand and the location's brand.

By relating the university to familiar locations, the newspapers fostered a geographical context for the university, which, by extension, tied the university to multiple communities, such as the City of Oshawa, the Durham Region, and the Greater Toronto Area (GTA). These relationships helped define who the university served and its impact on the surrounding areas. At the same time, however, an overly heavy focus on the local or regional characteristics of UOIT may have undermined efforts to develop the university's 
research mandate. Small, regional universities tend to be seen as focusing on primarily undergraduate teaching rather than research and graduate programs. As the university grew in size, it needed to continue to build its reputation by attracting faculty members with strong research programs (Linton, Tierney, \& Walsh, 2011; Ressler \& Abratt, 2009). To do so, it was important for the university to create a provincial and national identity.

It was from the traditionally blue-collared city of Oshawa and the surrounding communities that the bulk of the first cohort of students would come. At a local level, journalists used Oshawa, Ontario (with a population of about 150,000) as a reference point when defining the university's location (Kalinowski, 2003c; Urquhart, 2004a). In many cases, these descriptions were used in conjunction with possessive syntaxes: the "new Oshawa institute" (Josey \& Rushowy, 2001), "Oshawa's UOIT" (UOIT Ready," 2003), the "Oshawa school" (Irish, 2004), and "the Oshawa university" (Ruta, 2002). This use of possessive language helped foster the sentiment that the school belonged to, and would benefit, the community of Oshawa. When asked to describe the relationship between UOIT and Oshawa, one administrative staff member stated that UOIT's impact was positive: "I feel like it's brought class, it's brought diversity, it's just forced the community to think outside of the box and to not be this sheltered little blue-collared town-or city-that it's been labelled in the past" (Hunt, 2010). The sentiment that UOIT would act as a positive force within Oshawa was repeated in several interviews conducted by the Voices of UOIT project.

In addition, UOIT was rhetorically tied to the Durham Region, a vast area with over half a million people living in cities, towns, and rural communities. The university was often framed as a positive development for the region, with the announcement of the university being referred to as "phenomenal news for Durham Region" (Rusk, 2001), an "important addition" (Brennan, 2004a), and a "profound resource" (Hanes, 2001). Journalists and other commentators often noted the growth rate in the region as a compelling reason for the creation of a regional university; for example, Diane Cunningham, Ontario's Minister of Training, Colleges, and Universities at the time, stated, "Durham-one of the fastest growing regions in the province-needs a university" "OIT University," 2001). Furthermore, some journalists emphasized UOIT's proximity to Toronto by using directional words, such as "the eastern portion of the Greater Toronto Area" (Rusk, 2001) and "the area east of Toronto" (Brennan, 2004a). UOIT's catchment area was also described as reaching beyond Oshawa: "[of] the 60 per cent of students who don't hail from the immediate area, most are from other parts of the GTA" (Kalinowski, 2003b). From a public relations perspective, UOIT benefitted from a geographically expansive context. As one administrative staff member stated, "there was a lot of discussion around the Oshawacentric [university] versus Durham and even GTA[-centric university], and trying to help people see that this just wasn't an Oshawa university; it really was a university for east of Toronto" (Sunstrum-Mann, 2012).

\section{Educational Landscape}

Given the large number of universities in Ontario (as of 2014, 22 publicly funded universities (Government of Ontario, 2014), UOIT needed to stand out provincially and nationally as providing something new for Ontario students. Whetten and Mackey (2002) and Baron (2004), among others, have noted the importance of organizations being similar to each other (sharpness, in Baron's terms) while also being unique (resonance). 
Uniqueness allows organizations to stand out and create a niche. In UOIT's case, being a laptop university and having professionally oriented programs provided that sense of difference. Indeed, it might be argued that UOIT would never have been created if it had been designed to be exactly the same as existing universities. The university's uniqueness was highlighted in phrases such as "the only university in the province to offer a nuclear engineering degree" (Kalinowski, 2003a) and "Ontario's first laptop based university" ("UOIT Ready," 2003). These sentiments were echoed on a national scale in references to UOIT as "Canada's first wireless campus ... [and] the only school in Canada to offer bachelor's degrees in nuclear engineering and radiation sciences" (Kalinowski, 2003a). In addition, UOIT's broader impact was emphasized by statements from Polonsky claiming that UOIT would "be a major provider of professional personnel for all of Ontario" (Hanes, 2001).

While uniqueness helps differentiate one organization's identity from another's, an organization's identity is also tied to its ability to "fit in" with others similar to it (Baron, 2004; Whetten \& Mackey, 2002; Whetten, 2006). From the time UOIT was first announced, it struggled to establish its place within the broader educational landscape of Ontario largely due to the factors that made it unique. Despite its status as a full-fledged university, confusion and criticism resulted from UOIT's unorthodox name, vocational mandate to provide professional programs, and connection with Durham College.

The early confusion over UOIT's name and role held the potential to derail UOIT's growth, since an organization must have a clear identity that makes it recognizable, visible, and relevant if it is to be successful in integrating and interacting in its social environment (Brown et al., 2006; Oelsner, 2013; Ressler \& Abratt, 2009). The first name floated for the new university was the Ontario Institute of Technology (OIT), which was intended to convey the university's focus on applied professional programs in engineering and business, while also evoking an image of the prestigious Massachusetts Institute of Technology (MIT). According to Treadwell (2003), an organization's name must have image and function: "image helps the firm establish a distinctive picture of what it does; function means the name is readily comprehensible" (p. 189). In the case of UOIT, its organizational labels were closely tied with the name of the university, especially since the use of "Institute of Technology" suggests a function quite different from that of the established Ontario universities. As one founding Dean stated:

Their focus group studies told them that they should put "university" somewhere in the title or else it would never be recognized as a university. It would never achieve status as anything other than a polytechnic. And polytechnics have not gone over well in Ontario. (Hinch, 2010)

While this interviewee's words hint at the complicated educational landscape into which UOIT was born, journalists positioned UOIT within this landscape when they used organizational descriptions to communicate the university's identity. The other names considered, such as Durham University or University of Oshawa, seemed to reflect too narrow a vision of a regional university in a small, blue-collar city.

The use of labels and qualifiers such as "polytechnic school" (Ibbitson, 2001), "technical university" (Brennan, 2004a), and "technological university" (Brennan, 2004a) created confusion because few other Canadian universities had similar terminology and because Ontario's community colleges were generally viewed as being technology-focused 
and career-oriented. Some interpreted the use of words such as "technical" and "technological" as hedges or qualifiers that attempted to classify UOIT as a special kind of institution and not a full-fledged university. One article even suggested that the Ontario government was planning to create "institutes of technology-institutions that combine college and university courses-to provide curriculums tailored for the job market" (Mackie, 2001). Therefore, the positioning of UOIT as an "institute of technology" is a critical diction moment because it reveals the underlying assumptions and misconceptions that the university faced while establishing its identity.

Journalists also attempted to place UOIT within the provincial educational landscape by describing its mandate as "an anchor institution to provide a skilled and trained workforce" ("OIT University," 2001) and a "career-driven university" (Kalinowski, 2004b). While these words may seem innocuous, within Canada's higher education community, they raised questions about the role of universities by highlighting the difficult balance between the theoretical and practical aspects of post-secondary education. In addition, some journalists were confused about the degree-granting status of the university, stating that UOIT would be a "post-secondary institution that will offer both college diplomas and university degrees" ("Ontario," 2001). Although there was never an intent to create a university college, the confusion is understandable since the university shared a campus and some services with Durham College, the president of the university for its first year was also the president of the college, and because university colleges had been created in other Canadian provinces in recent years.

This interconnected relationship between UOIT and Durham College caused much confusion, with some journalists writing that UOIT would "merge with Durham College" ("Oshawa Lands," 2001) and others describing the relationship as one with a "seamless integration" (Hanes, 2001). Some journalists saw the relationship as a "college and university partnership" (Kalinowski, 2003b), while others noted that they simply shared grounds. In one case, the journalist used an undefined and ambiguous term, "affiliated university" (Warson, 2002), to describe UOIT's organizational identity and its relationship with the college. In fact, the university's opening concerned some residents, who feared the university would replace this long-standing institution. As Catherine Drea (2011), project manager for the university at the time, explained: "people called from the community to ask if we had taken over the college, [asking] is there still going to be a college, my son or daughter is applying to college, or do we apply to you?"” Other interviewees also mentioned interactions with community members that revealed confusion. As an administrative staff member, Vivien Ricard (2010) recounted: "A year ago, I was telling somebody that it was the university and they said, 'Oh you're at Durham College.' I said, 'Well, I'm at the university,' and he said, 'Oh, that's what they're calling it now.'” The combination of UOIT's unusual relationship with the college, its name, and its mandate fed much of the confusion and the criticism about the new institution.

The media also relayed some of the criticism from the broader higher education community that surrounded the university's birth and strained the early credibility of UOIT's identity. For instance, journalists reported that "the Ontario Undergraduate Student Alliance believe the Ontario Institute of Technology 'isn't really a university at all” (Josey \& Rushowy, 2001), referred to sceptics "who [said] it's nothing more than a trumped up community college" (Kalinowski, 2003a), and quoted critics who called UOIT a "com- 
munity college with ivory tower pretensions" (Kalinowski, 2003b). These criticisms directly questioned UOIT's legitimacy but also reflected the confusion around its place in Ontario's system of post-secondary education. Furthermore, individuals such as Tracy Boyer from the Ontario Community College Student Parliamentary Association believed that UOIT would disrupt the existing educational landscapes and undermine the college system: "we strongly feel the creation of (more) polytechnics will create three tiers in Ontario and reduce the position of colleges" (Josey \& Rushowy, 2001).

Beyond the question of legitimacy, criticism was also directed towards UOIT's mandate as an institution with professionally oriented programs, which raised the spectre of a market-oriented university that eschewed the theoretical in favour of the practical; as Buchbinder and Newson (1990), among others, have argued, "the goals of research and the development of knowledge are more and more linked to the production of marketable products than social knowledge" (p. 355). One reporter remarked that "the idea of a nontraditional, career-oriented university has drawn more than the usual scepticism from the more established halls of academe" (Kalinowski, 2003b). Buchbinder and Newson's (1990) critiques were echoed in reports that "the existing universities also worried that the 'market-driven' basis of their new partner in Oshawa would compromise academic freedom" (Urquhart, 2004a). Another aspect of the debate raised the idea that businesses, not universities, should be providing skills training. As the executive director of the Ontario Undergraduate Student Association, Bryce Rudyk, was quoted in the Toronto Star to have said: “you don't create universities to serve business and the private sector. ... it's not really giving students an education but training" (Josey \& Rushowy, 2001). In many respects, the creation of UOIT as a "market-driven" university was simply an extension of the push for all of Canada's universities to establish linkages with corporations, which had begun in the 1980s (Buchbinder \& Newson, 1990; Orr, 1997) and continues today.

The founding members of UOIT regularly countered the misinformation and critiques related to its name by repeatedly clarifying the university's status. In a 2001 Toronto Star article (when the name was Ontario Institute of Technology), Polonsky clearly stated: "it is not a polytechnical university, not a technical university, not a 'university college'. It's a university" (Hanes, 2001), but he also "acknowledge[d] the chance for mis-impressions, given that 'university' is not part of the school's name and 'technology' is, 'but no one will be thinking that three years from now"' (Hanes, 2001). Others made similar attempts to counteract confusion over the university. One lecturer recalled:

I think at the beginning, the biggest problem was just people hadn't heard of us, especially once you left the Durham Region. . . for my part I always wore a UOIT T-shirt, as much as possible. When I went out, I had a UOIT T-shirt, and people would ask me, they'd go, 'What's that, what school is that?' And I'd be happy to talk about it. (Brar, 2011)

The founding provost, Michael Finlayson, was quoted as saying that "much of the criticism is 'based on an out-of-date concept of the institution. There is virtually no overlap between the faculty of the university and the college. There is no overlap between the academic programs" (Kalinowski, 2003a). Other newspapers portrayed a more positive approach, as seen in the comment of Marc Rosen, Dean of Engineering, that "this is a career-driven, market-oriented university and you won't find anything like this elsewhere in Canada" ("University of Top Jobs," 2003). 


\section{The Politicizing of UOIT's Birth}

In 2003-2004, the framing of the university adopted a political tone, especially relating to its creation and mandate. Most articles in the local Metroland paper tended to apolitically assign the university's creation to founder Gary Polonsky, also known as UOIT's "proud papa" ("Bring Out," 2003). However, the Toronto Star framed the university as a creation of the provincial Conservative government. Many articles in 2004 included statements such as "the university is a creation of Ontario's former Tory government" (Brennan, 2004b) and "the new university was created by the former Conservative government" (Kalinowski, 2004a). By pairing the university's creation with the Conservative government, the Toronto Star created a sense of Conservative ownership and political alignment and implied that the idea for the university originated from within the Conservative party. Nowhere is this implied more clearly than in a Toronto Star article subheadline that refers to UOIT as the "Tories' pet project" (Brennan, 2004a).

The newspaper further politicized the institution by framing its creation as a purposeful political manoeuver designed to attract votes and cater to the private sector. In some cases, this was expressed indirectly by pointing out UOIT's proximity to the ridings of two prominent Conservative Members of Provincial Parliament: Minister of Finance Jim Flaherty's riding of Whitby-Ajax and Minister of Education Janet Ecker's riding of PickeringAjax-Uxbridge (Kalinowski, 2003a; Kalinowski 2003b; Urquhart, 2004a). Furthermore, UOIT's legitimacy was undermined by claims that the university fulfilled the Conservative agenda to cater to big business. Like Rudyk's 2001 comment about the university's mandate (Josey \& Rushowy, 2001), in 2003, Henry Mandelbaum, then Executive Director of the Ontario Confederation of University Faculty Associations, was quoted as saying: "The Conservatives are really driven by this notion of meeting private sector needs. They want to have an education that's immediately job relevant. One would think that's what the college system would do" (Kalinowski, 2003a).

Once power shifted from a Conservative government led by Mike Harris to a Liberal government led by Dalton McGuinty after the 2003 provincial election, UOIT was placed at odds with the new Liberal government because it had been marked as a Conservative creation, a situation that was exacerbated in early 2004 when UOIT needed to secure a loan from the province to continue the university's expansion. As John Perz (2010), Associate Dean of Science at the time, explained:

When the government changed from the Conservatives to the Liberals, no one knew us. All of a sudden, the Liberals said, "Who are these people?" ... We were seen at one point as being the creature of one kind of government and maybe they should rethink this.

This aligned closely with the observation by the Toronto Star that the "Liberals feel no connection with the school because it was a creation of the former Conservative government" (Brennan, 2004a). The Star also noted that "privately, representatives of the Liberal government also expressed concerns that UOIT was an example of pork-barrelling by the previous Conservative regime" (Urquhart, 2004b). The paper further suggested that the Liberals viewed UOIT's leadership as allies of the Conservative party: "mixed into this decision-making equation are questions about Polonsky, whom the Liberals saw as cozy with members of the previous Conservative government, notably Flaherty" (Urquhart, 2004b). 
In its coverage of the 2004 UOIT loan negotiations, the Toronto Star painted an adversarial relationship between the university and the Liberal government. For instance, the paper stated that "the new Liberal government at Queen's Park is playing hardball with the Ontario Institute of Technology" (Urquhart, 2004a). The idiom "playing hardball" generally suggests using forceful, uncompromising, and combative methods. Furthermore, the paper also suggested the Liberals could close the university, saying "[m]any of the province's 18 other universities would applaud if the Liberals were to pull the plug on the institute" (Urquhart, 2004a). The phrase "pull the plug" fostered the idea that the Liberal government might terminate the institution, which the paper depicted as belonging to the previous regime. The politicized diction, combined with other descriptive choices, portrayed UOIT in a negative light. As a final example, this sub-headline at the beginning of a 2004 article showcased some of these observations: "Durham technical school won't get Queen's Park help. No loan guarantee from Liberals for Tories' pet project" (Brennan, 2004a). Here, the author has misnamed the university as a technical school, thereby diminishing its legitimacy and merit, while also politicizing and belittling the institution by referring to it as a pet project.

Overall, many instances of particular language politicized the university by creating associations between it and the Conservative party through topic and language choice. The Toronto Star, in particular, attributed UOIT's creation to the Conservative party by directly referring to the institution as a Conservative product, discussing key Conservative figures involved in the process, framing it as a political manoeuver to gain votes, and suggesting that the Conservative government created the university to serve the private sector. Finally, during the period when the university required a loan from the newlyelected Liberal government, the newspaper used specific diction to portray adversarial tensions between the university and the Liberal party.

The Star's depiction of UOIT as a political entity, however, contrasts with the stories told by the community members, staff, administration, and professors interviewed for the Voices of UOIT project. While there were occasional mentions of politics, such as travelling to Queen's Park to lobby for the university's creation or meeting with politicians, the overall message of the interviews comes across as a story of a handful of dedicated individuals working to realize a long-standing idea of a university in Oshawa. In fact, city councillor Nancy Diamond stated that when "[she] was first elected as a councillor in December of 1988, part of [her] platform was that [she] believed that Durham should have a university" (Diamond, 2011), which was well before the Harris Conservatives were elected in 1995. Furthermore, none of the interviewees suggested that the idea of the university originated from within the Conservative party, as the label of "Conservative creation" implies. Most interviewees pinpointed Gary Polonsky as the main visionary behind UOIT; as Nancy Diamond (2011) went on to state,

Gary's vision, without Gary's intestinal fortitude, Gary would say guts, this would not have happened. You had to have a Gary Polonsky as the centre, the driver, the dreamer, the everything, and then he gathered people around he knew who would support it.

It is certainly true that Gary Polonsky gathered Conservative party members to help support his vision, which seems sensible considering they were in power at the time, but it does not render the university as a Conservative "pet project" or "creation," as the newspaper regularly suggested. 


\section{Conclusion}

Our qualitative analysis of newspaper reports about the founding and first year of UOIT provide insights into how the university's identity was created and portrayed by the media and perceived by observers. The media reports positioned UOIT's identity in three main ways: through geographic labels, references to the nature of UOIT's educational mandate, and as a political entity. Our findings suggest that further research on the influence of the media on the identity creation of other, well-established universities would add to an understanding of how universities, as they evolve, are viewed. From an organizational identity and public relations perspective, this research demonstrates that for UOIT-as a new university working to establish its organizational identity and a strong reputation in order to convince potential students to take a chance on it-the role of the media was key. Many news reports created an image of UOIT that was at odds with the intended identity of the founding administrators and faculty members, who were working to attract not only students but also a professoriate with the potential to build an excellent university through strong teaching and research.

The formative years of an organization are important in establishing its reputation, identity, and sense of belonging within its community. Similarly, when a university rebrands or works to shift its identity, the experience of UOIT can provide some insights. For instance, monitoring the organization's portrayal in the press is extremely important, as that portrayal can influence community perceptions and affect the decisions of policy makers, potential students, and nearby residents. While new organizations struggle to balance many diverse demands, from creating an organizational structure to hiring and budget challenges, the ability to track trends in the institution's media coverage and identify threats may prove to be an invaluable dedication of resources. In addition, institutions must have strategies in place to counter public relations threats, such as methods to address community concerns before they become divisive public issues or permanent misconceptions. For established universities, this point is also relevant. In Canada recently, some large, well-established universities have had to deal with sensitive student actions that hold the potential to tarnish the university's reputation, such as the actions of some of Dalhousie University's dentistry students (Colley \& Gorman, 2014; Tryon \& Logan, 2015) and the University of Ottawa's male hockey team (Bradshaw 2014; Chiose 2015). Not only do the affected universities need to be seen to be addressing the problems, but other universities also need to demonstrate that they are being proactive in preventing similar problems on their campuses.

For new universities such as UOIT, the location of the university and its name are important in forming identity. The founding administration and faculty work to define the organization and create an identity that fits their vision. At the same time, however, they must navigate the political and legal constraints imposed on all universities, and they must do so while convincing students (and their parents) to take a chance on a new university in a province (and country) with many well-established ones. The importance and complexity of both fitting into the educational landscape by meeting the legal requirements of universities while also differentiating the new institution from established universities is demonstrated here. The unique mandate of being a market-oriented university offering professional programs set UOIT apart from the established universities, but it also created a challenge because UOIT was seen as not being like a "real" university. 
The interplay between the insider and outsider perceptions of UOIT is important in defining the organization. Reputation in the sense of judgements about the quality of the university was virtually non-existent when the first students enrolled and the first faculty members were hired. Similarly, the university's brand was still being defined, alongside its identity. King and Whetten's (2008) research on legitimacy and reputation is important here, as both are still being built at UOIT. Today, UOIT is no longer considered a small university; from some 900 students when it opened its doors in 2003, it has grown to about 10,000 students in 2014-15, with over 250 academic faculty members and over 300 non-academic staff (UOIT, 2014). That UOIT has attracted significant amounts of research funding (more than \$11 million in 2013-14), including several Canada Research Council Chairs, demonstrates its acceptance and legitimacy within the broader Canadian educational landscape. The success of the university at its 10-year anniversary illustrates how a university can overcome negative images through hard work and persistence. This success will ultimately define UOIT’s identity, legitimacy, and reputation as a university.

\section{Note}

1. In Ontario, colleges of applied arts and technology were created in 1965 to offer certificate programs, diplomas, and apprenticeships oriented towards job training. In recent years, some colleges have been allowed to offer applied degree programs. Universities offer undergraduate and graduate degrees, as well as professional degree programs. Although in the United States the terms college and university are often conflated, in Ontario the two terms refer to different types of educational institutions.

\section{Acknowledgements}

The Voices of UOIT oral history project was funded by the Office of the Provost, UOIT. The project was led by Shirley Van Nuland and Alyson E. King. Sierra McKenzie's research was conducted for her summer Undergraduate Research Award and for her honour's thesis, which were supervised by Alyson King. The authors thank the anonymous reviewers for their thorough and insightful comments on an earlier version of this paper.

\section{References}

Alessandri, S. W., Yang, S., \& Kinsey, D. F. (2006). An integrative approach to university visual identity and reputation. Corporate Reputation Review, 9(4), 258-270.

Baron, James N. (2004). Employing identities in organizational ecology. Industrial and Corporate Change, 13(1), 3-32.

Bradshaw, J. (2014, March 3). University of Ottawa men's hockey team suspended over alleged sex assault. The Globe and Mail. Retrieved from http://www.theglobeandmail. com/news/national/university-of-ottawa-suspends-hockey-team-over-seriousmisconduct/article17201525/

Brar, R. (2011, June 24). Interview with Megan Johnson. Voices of UOIT Project. Oshawa, ON.

Brennan, R. (2004a, February 5). University's expansion in doubt. Toronto Star, p. Bo1.

Brennan, R. (2004b, May 17). Risks seen in backing loan to new university. Toronto Star, p. Ao8. 
Bring out the cheerleaders, strike up the band. (2003, August 29). Oshawa This Week, n.p.

Brown, T. J., Dacin, P. A., Pratt, M. G., \& Whetten, D. A. (2006). Identity, intended image, construed image, and reputation: An interdisciplinary framework and suggested terminology. Journal of the Academy of Marketing Science, 34(2), 99-106.

Buchbinder, H., \& Newson, J. (1990). Corporate-university linkages in Canada: Transforming a public institution. Higher Education, 2O(4), 355-379.

Carter, S. M. \& Deephouse, D. L. (1999). “Tough talk" and "soothing speech": Managing reputations for being tough and for being good. Corporate Reputation Review, 2(4), 308-332.

Chapleo, C. (2010). What defines "successful" university brands? International Journal of Public Sector Management, 23(2), 169-183.

Chiose, S. (2015, January 13). University of Ottawa sued over suspension of hockey team. The Globe and Mail. Retrieved from http://www.theglobeandmail.com/news/ national/university-of-ottawa-sued-over-suspension-of-hockey-team/article22432545/

Colley, S. B., \& Gorman, M. (2014, December 16). Dal ponders expulsions over "deeply disturbing" posts by dentistry students. Herald News. Retrieved from http:// thechronicleherald.ca/metro/1258156-dal-ponders-expulsions-over-\%E2\%80\%98deeplydisturbing\%E2\%80\%99-posts-by-dentistry-students

Diamond, N. (2011, July 20). Interview with Sierra McKenzie. Voices of UOIT Project. Oshawa ON.

Drea, C. (2011, July 18). Interview with Jonathan Wallace. Voices of UOIT Project. Oshawa, ON.

Dutton, J. E., \& Dukerich, J. M. (1991). Keeping an eye on the mirror: Image and identity in organizational adaptation. The Academy of Management Journal, 34(3), 517-554.

Glynn, M. A., \& Abzug, R. (2002). Institutionalizing identity: Symbolic isomorphism and organizational names. The Academy of Management Journal, 45(1), 267-280.

Glynn, M. A., \& Navis, C. (2013). Categories, identities, and cultural classification: Moving beyond a model of categorical constraint. Journal of Management Studies, 5o(6), 1124-1137. doi:10.1111/joms.12023

Government of Ontario. (2014). Ontario universities. Retrieved from http://www. ontario.ca/education-and-training/ontario-universities

Hanes, T. (2001, August 16). New university will have horse sense. Toronto Star, p. Ko1.

He, H., \& Baruch, Y. (2009). Transforming organizational identity under institutional change. Journal of Organizational Change Management, 22(6), 575-599. doi:10.1108/09534810910997014

Hinch, R. (2010, July 22). Interview with Jennifer Glover. Voices of UOIT Project. Oshawa, ON.

Hsu, G., \& Hannan, M. T. (2005). Identities, genres, and organizational forms. Organization Science, 16(5), 474-490. 
Hunt, L. (2010, July 22). Interview with Jonathan Wallace. Voices of UOIT Project. Oshawa, ON.

Ibbitson, J. (2001, May 25). Fearless columnist gets it half right. The Globe and Mail, p. A10.

Irish, P. (2004, January 27). Oshawa school is cutting edge. Toronto Star, p. Bo5.

Josey, S., \& Rushowy, K. (2001, October 5). Colleges' status on rise, says minister. Toronto Star, p. Bo4.

Kalinowski, T. (2003a, February 4). A field of Ivy League dreams. Toronto Star, p. Bo1.

Kalinowski, T. (2003b, September 20). Path to university covered in dust. Toronto Star, p. Ho1.

Kalinowski, T. (2003c, December 27). Gary Polonsky. Toronto Star, p. Bo2.

Kalinowski, T. (2004a, April 21). New university picks Lyn McLeod as chancellor. Toronto Star, p. Bo2.

Kalinowski, T. (2004b, June 3). New university mints first grads. Toronto Star, p. Bo1.

Kim, S., Carvalho, J. P., \& Cooksey, C. E. (2007). Exploring the effects of negative publicity: News coverage and public perceptions of a university. Public Relations Review, $33,233-235$.

King, B. G., \& Whetten, D. A. (2008). Rethinking the relationship between reputation and legitimacy: A social actor conceptualization. Corporate Reputation Review, 11, 192207. doi:10.1057/crr.2008.16

Lamertz, K., \& Heugens, P. P. M. A. R. (2009). Institutional translation through spectatorship: Collective consumption and editing of symbolic organizational texts by firms and their audiences. Organization Studies, 30(11), 1249-1279.

Leeper, K. A, \& Leeper, R. V. (2006). Crisis in the college/university relationship with the community: A case study. Journal of Promotion Management, 12(3/4), 129-142.

Li, W., \& Wyer, R. (1994). The role of country of origin in product evaluations: Informational and standard-of-comparison effects. Journal of Consumer Psychology, 3(2), 187-212.

Linton, J. D., Tierney, R., \& Walsh, S. T. (2011). Publish or perish: How are research and reputation related? Serials Review, 37(4), 244-257.

Mackie, R. (2001, October 4). New college in Ontario to be hybrid; Institute of technology set to open in 2003; Province gives \$60-million for construction. The Globe and Mail, p. A21.

McQuarrie, F. A. E., Konda, A. Z., \& Lamertz, K. (2013). Government, coercive power and the perceived legitimacy of Canadian post-secondary institutions. Canadian Journal of Higher Education/Revue canadienne d'enseignement supérieur, 43(2), 149-165.

Oelsner, A. (2013). The institutional identity of regional organizations, or Mercosur's identity crisis. International Studies Quarterly, 57, 115-127. doi:10.1111/isqu.12033

OIT university bill introduced. (2001, November 28). Oshawa this Week, n.p. 
Ontario to announce university. (2001, October 4). Toronto Star, p. A16.

Orr, L. (1997). Globalisation and universities: Towards the "market university"? Social Dynamics, 23(1), 42-67.

Oshawa lands new university. (2001, May 10). Toronto Star, n.p.

Perz, J. (2010, May 25). Interview with Jennifer Glover. Voices of UOIT Project. Oshawa, ON.

Ressler, J., \& Abratt, R. (2009). Assessing the impact of university reputation on stakeholder intentions. Journal of General Management, 35(1), 35-45.

Ricard, V. (2010, June 22). Interview with Jonathan Wallace. Voices of UOIT Project. Oshawa, ON.

Rusk, J. (2001, August 6). University "phenomenal news" for Oshawa; Ontario Institute of Technology could draw knowledge-based industry into Durham. The Globe and Mail, p. A12.

Ruta, M. (2002, June 5). Will opportunity knock for local university? Durham Region.

Stets, J. E., \& Burke, P. J. (2000). Identity theory and social identity theory. Social Psychology Quarterly, 63(3), 224-237.

Sunstrum-Mann, L. (2012, July 23). Interview with Caitlin Dougherty. Voices of UOIT Project. Oshawa, ON.

Treadwell, D. F. (2003). Can your institution's name influence constituent response? An initial assessment of consumer response to college names. Public Relations Review, 29, 185-197.

Tryon, J., \& Logan, N. (2015, May 21). Dalhousie dentistry students break silence on “Gentlemen's Club” Facebook scandal. Global News. Retrieved from http://globalnews. $\mathrm{ca} /$ news/2010585/dalhousie-dentistry-students-break-silence-on-gentlemens-clubfacebook-scandal/

University of Ontario Institute of Technology. (2014, August). UOIT Fact Book 20132014 v2.o. Retrieved from http://uoit.ca/sites/oira/university-data/fact_book/20132014\%20Fact\%20Book\%20Word\%20Version\%203.0\%20Oct\%2010,\%202014.pdf

University of top jobs. (2003, April 10). Toronto Star, p. Ko1.

UOIT ready for inaugural class. (2003, July 2). Oshawa This Week, n.p.

Urquhart, I. (2004a, February). Oshawa institute plan for growth on hold. Toronto Star, p. A01.

Urquhart, I. (2004b, July 21). MIT of the North set to expand. Toronto Star, p. A17.

Warson, A. (2002, September 3). New university to break ground; UOIT will share Durham College site and build in stages to allow school time to raise money. The Globe and Mail, p. B13.

Whetten, D. A. (2006). Albert and Whetten revisited: Strengthening the concept of organizational identity. Journal of Management Inquiry, 15(3), 219-234. 
Whetten, D. A., \& Mackey, A. A. (2002). A social actor conception of organizational identity and its implications for the study of organizational reputation. Business and Society, 41(4), 393-414.

\section{Contact Information}
Alyson E. King
Faculty of Social Science and Humanities
University of Ontario Institute of Technology
alyson.king@uoit.ca

Sierra McKenzie obtained her Bachelor of Arts in Communication (Honours) from the University of Ontario Institute of Technology (UOIT) in 2013. Since then, she has been working towards her goal of becoming a Speech Language Pathologist and currently volunteers at the Toronto Western Hospital and the E.W. Bickle Centre for Complex Continuing Care. In addition, she is pursuing part-times studies at the University of Toronto. Sierra has worked as a research assistant on numerous projects, including the Voices of UOIT oral history project, which is exploring the founding of Canada's newest university.

Alyson E. King is an assistant professor and the program director in the Community Development and Policy Studies program in UOIT's Faculty of Social Science and Humanities. Dr. King's research concentrates on improving equity in communities and institutions through increasing accessibility in education and raising awareness of barriers to equity. She conducts research on supported education for persons living with mental illness, student experiences at university, academic integrity, student persistence and success, and (multi)literacies in the knowledge economy. 